\title{
Reflections on methodology for and the importance of indicators for campus sustainablity - a Lithuanian case study
}

\author{
Authors: Diana Cibulskiene, Vèjūnè Laurinavičiūtè, Gaivilè Nemeišytè, Renata \\ Osockyte, Raimunda Urbelytè, Žygimantas Kupstys, Eivydo Čuluunpurevas, \\ Joost Platje
}

\begin{abstract}
Aim: Provide a summary of the discussion of focus group 2 at the workshop on "Methodology for assessing the campus sustainability from the perspective of multi-level antifragility" held in June 2016 at Siauliai University (Lithuania), as well as reflection notes each of the participant wrote after the workshop. The paper shows the outcome of the process of interaction and reflections of the authors.

Design / Research methods: This article contains feedback based on the experience and ideas from third year students from sustainable business from the University of Siauliai (Lithuania). Discussion took place during the workshop in focus groups. Afterwards, a discussion took place among all participating students and lecturers. After the workshop, the authors wrote individual feedback notes. These are summarized in this paper.

Conclusions / findings: When using a wider set of indicators of campus sustainability showing different types of fragilities, different stakeholders need to be used as a source of information. The reason is that when not possessing information on a certain aspect, as was confirmed by this focus group, an indicator tends to be considered irrelevant. A conclusion that should be treated with care is that indicators of lying and cheating, honesty, as well as indicators of mistakes may be a good starting point for creating indicators of campus sustainability focusing at threats for organizational viability and sustainability of the university's external environment.
\end{abstract}

Originality / value of the article: The article provides critical feedback on an innovative approach towards research on campus sustainability.

Eivydo Čuluunpurevas

Siauliai University

e.culuunpurevas@gmail.com

Joost Platje

WSB University in Wrocław

johannes.platje@wsb.wroclaw.pl 
Keywords: campus sustainability, sustainability management, fragility, antifragility, methodology

JEL: Q01, B40, 123

\author{
History: received 2016-11-25, \\ corrected 2016-11-27, accepted \\ 2016-11-27
}

\section{Introduction}

Altogether, in Lithuania there are twenty universities and according to the magazine "Rating", in the year 2015, Siauliai University has taken the sixth place among the all universities (Pukenè 2015). It consists of three faculties: the faculty of social science, humanities and arts, faculty of technology, physical and biomedical sciences and the faculty of education science and social welfare. In the year 2015, 2273 students enrolled at the university. This is a serious decline compared to the more than 12000 students enrolling just after the university's establishment in $1997 .{ }^{1}$ In this context, the authors reflect upon indicators for campus sustainability discussed at the workshop on this topic, held at Siauliai University in June 2016.

A summary of the discussion of focus group 2 of third year students from Sustainable Business as well as reflection notes each of the participant wrote after the workshop is provided. The paper shows the outcome of the process of interaction and reflections of the authors. First, some methodological issues are discussed. Then, reflections in indicators of campus viability and the university's impact on its external environment are presented.

\section{Methodology}

Two difficulties appeared in the discussion on the questions and indicators regarding campus sustainability.

\footnotetext{
1 Siauliai University Website, http:// www.su.lt/index.php?option $=$ com conte nt\&view $=$ article \&id $=167 \&$ Itemid $=5520$ \&lang=lt [20.06.2016].
}

a. Participants differently understood the notions of campus viability and external sustainability.

b. Some indicators were considered to be ambiguous in their meaning.

While this was a stimulus for discussion into the nature of the importance of different indicators, the indicators need a clear, specified meaning when applying them in order to compare different universities. For example, when discussing the issue of mistakes or hiding the truth, the question appeared "what type of mistakes" or what kind of truth we were talking about. This discussion created consciousness regarding the effects of different types of mistakes.

Another issue concerned the different approach to the first and the second part of the questionnaire. The respondents had to answer the questions from the first part in the context of their own university. The second part contained indicators which should be assessed on their relevance for organizational viability and sustainability of the external environment in general. This part of the questionnaire required a more abstract, generalistic approach, compared to the home-university specific questions in the first part. A problem was that some of the participants reflected on part 2 with their home university in mind. This created a challenge in the group discussion.

Quite often it was argued that an indicator was not relevant as a participant had never experienced such a situation (e.g., ignorance of critique by the university management) or the indicator did not concern them (lack of parking space for those not possessing a car). This is a more general problem in 
identifying fragilities (which are often difficult to identify as they are often non-visible or difficult to observe) when people have never observed something or experienced something, they tend to assess this as unimportant (compare Kahneman 2011).

\section{Indicators of campus viability and sustainability}

While some disagreement existed at the beginning, after the discussion most of the time consensus was reached about the relevance of indicators. First of all, lack of knowledge was often mentioned in the individual reflection notes. A lack of knowledge of graduates from the university was assessed as a low probability event that eventually could lead to serious impact on the organizational viability. The argument was that the student $\mathrm{him} /$ herself has the largest influence on whether he/she will absorb information and gain knowledge. When a graduate has too little knowledge, the reputation of the university among the employers may be damaged. As a consequence, there is an incentive for the teacher to support the development of knowledge enabling students to function on the labour market, as this otherwise would negatively influence student numbers in the future. This is of particular relevance in the context of the declining number of students at Siauliai University. A challenge identified by participants is that the curriculum contains too few elements of sustainable development while scientists do little research in this area.

However, as came up in the discussion, many students may think that obtaining a diploma is more important than knowledge. A reason may be that the student does not realize him/ herself that while a diploma is needed to enter the labour market, different types of knowledge are required to stay on the labour market.
Interestingly, no reflection was made regarding the importance of knowledge for sustainability of the external environment. It was acknowledged in the discussion that many indicators and questions are interrelated. Examples are hiding the truth, high secrecy, lack of honesty and lying and cheating. While the probability that hiding the truth or secrets have a negative impact on organizational viability was thought to be low, one important unsaid thing may destroy a university's reputation. As the university is an important factor in local development, such an event is also relevant for the external environment. Many participants in the group mentioned that when truth is hidden, the sooner or later this will be revealed. This increases the likeliness of a negative impact on the organization. As mentioned, an important impact is loss of reputation, threatening organizational viability when it reduces the number of students. Now the question appears whether reputation is in fact an element of fragility, which can reduce long-term demand by students, the willingness of good lecturers and scientists to work at the university, a lack of funding, etc.

One example of a negative impact of hiding the truth or cheating by students "not having time to study" on the university's reputation is related to the fact that part of the students have a job besides their studies. The students who do not have a job are more likely to attend lectures and to spend more time at home for studying. While the level of knowledge and absorbed information may differ, some participants argued that grades received can be similar. In this case, the mark given does not reflect the truth about the student's knowledge. While this may have a negative impact on the incentives for non-working students to study, finally the diploma will not reflect differences in knowledge. Like before, also here the university's 
reputation may be seriously damaged when such information becomes public.

The existence of closed groups of family and friends as well as hiring family and friends were, with the exception of one participant, considered to be irrelevant. This was often due to the fact that such a situation was never observed. Another element that came up is that teachers have to provide a minimum level of knowledge in order not to lose students. As a consequence, it can be expected that hiring bad teachers will not be a fragility likely to appear when struggling for students in a situation where their numbers decline.

All indicators connected with mistakes were considered to be relevant, as mistakes are very easy to make. As a consequence, in general, their appearance is highly probable. Is there is a lack of information on the mistake, no learning process can take place and the mistake cannot be fixed. Students make a lot of mistakes while studying. The seriousness of these mistakes is low when feedback is provided. When this is not the case, or as discussed earlier, similar marks are given for good and bad work, students may graduate without proper knowledge. This may have a negative impact on sustainable development in the future, in particular when the amount of such students is large. A reason may be a lack of knowledge on sustainable development, but also a lack of ability to learn from mistakes, or even a mentality of hiding mistakes.

A problem identified related to learning from mistakes is a lack of critical discussion and asking questions during class. During the discussion some participants changed their mind on this issue. First, they considered it to be irrelevant, while at a certain moment recognizing the relevance of critical discussion and asking questions for uncovering mistakes and learning from them. People not used to critique will not get feedback and/ or not be open to feedback, may not learn as much from mistakes as they could. What makes an international comparison a challenge is that asking questions in some countries may culturally be seen as offensive to others. Knowledge of foreign language by staff was considered to be relevant, in particular when a university wants to increase the number of international students in the face of a declining amount of students from the home country. When knowledge of foreign language lacks among staff, foreign students may face serious difficulties in getting to know the rules at the university. When living in a dormitory where none of the employees speaks, for example, English, this not only makes life more difficult, but may also be dangerous in case of emergencies such as a fire or a serious illness.

Not surprisingly, cost reduction was identified as relevant. As discussed, the number of students declined significantly at Siauliai University during the last decades. Different faculties have merged and reorganization has taken place. A question remains whether this process will stop at a certain point, or that the university will be too small to survive individually at a certain moment.

\section{Concluding remarks}

The reflections presented in this paper should be interpreted with care. They are based on knowledge and experience of third year bachelor students of the Sustainable Business programme at Siauliai University in Lithuania.

An important issue that came up is that when a problem remains unseen, it is considered to be irrelevant. This is a standard problem with identifying fragilities (Taleb 2012), which, not surprisingly, was confirmed in the group discussion and reflection paper. 
Only discussion afterwards made the participants aware of this issue. However, even when being aware of the problem, it is incredibly difficult to do something with it in practice, as this requires skills and imagination.

Thus, due to a lack of knowledge and information among participants, a problem which to different extents can be expected in any type of group is that not all indicators can be discussed. When using a wider set of indicators of campus sustainability showing different types of fragilities, different stakeholders need to be used as a source of information. As such, the conclusion that indicators of lying and cheating, honesty, as well as indicators of mistakes may be a good starting point for creating indicators of campus sustainability should be interpreted with care. Other indicators which people are relevant because they lack knowledge about it may in reality reflect important fragilities, challenging campus sustainability.

\title{
Bibliography
}

Kahnemann D, (2011) Thinking, Fast and Slow, Farrar, Straus and Giroux, New York USA.

Taleb N.M. (2012), Antifragile - things that gain from disorder, Penguin Books, London.

Pukenè R. (2015), Geriausi Lietuvos Universitai ir Kolegijos, http:// www.delfi.lt/news/daily/education/ paskelbe-geriausius-lietuvos-universitetus-ir-kolegijas.d? id $=67885064$ [20.06.2016].

Siauliai University Website, http:// www.su.It/index.php?option $=$ com content\&view $=$ article \&id $=167$ 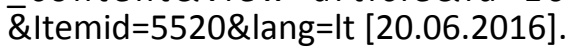

\section{Uwagi o metodologii wskaźników zrównoważonego rozwoju kampusu i ich znaczeniu - studium przypadku Litwy}

\begin{abstract}
Abstrakt
Cel: Tekst zawiera streszczenie dyskusji prowadzonych w grupie fokusowej nr 2 podczas warsztatów na temat „Metodologia oceny zrównoważonego rozwoju kampusu z perspektywy antykruchości wielopoziomowej" zorganizowanej przez Uniwersytet Szawelski na Litwie w lipcu 2016 r. oraz uwagi wynikające z notatek pozostawionych przez każdego uczestnika po warsztatach. Artykuł pokazuje wynik procesu integracji i refleksji autorów.

Metoda badawcza: Artykuł zawiera informacje zwrotną opartą na doświadczeniu i poglądach studentów trzeciego roku zrównoważonego biznesu z Uniwersytetu Szawelskiego na Litwie. Dyskusja miała miejsce podczas warsztatów i przebiegała w grupach fokusowych, a następnie z udziałem wszystkich uczestników i wykładowców. Po warsztatach uczestnicy byli proszeni o sporządzenie notatek z informacją zwrotną. Notatki te są streszczone w artykule. Wnioski: Użycie większej liczby wskaźników zrównoważonego rozwoju kampusu pokazujących różne typy kruchości pociąga za sobą konieczność uzyskania informacji z różnych źródeł. $Z$ tego powodu brak informacji na temat pewnego zagadnienia, co miało miejsce w tej grupie, traktowano jako wskaźnik nierelewantny. Wnioskiem, który należy przyjąć z ostrożnością jest to,
\end{abstract}


że kłamstwo, oszustwo i uczciwość, a także wskaźniki dotyczące błędów, mogą stać się dobrym punktem wyjścia dla opracowania wskaźników zróżnicowanego rozwoju kampusu skoncentrowanych na zagrożeniach żywotności organizacyjnej i zrównoważonego rozwoju środowiska zewnętrznego uniwersytetu.

Oryginalność / wartość artykułu, wkład w rozwoju nauki: Artykuł zawiera krytyczne informacje zwrotne na temat innowacyjnego podejścia badania zrównoważonego rozwoju kampusu.

Słowa kluczowe: zrównoważonego rozwoju kampusu, zarządzanie zrównoważonego rozwoju, kruchość, antykruchość, metodologia 